\title{
MELIMEX, an experimental heavy metal pollution study: Effects of increased heavy metal load on crustacea plankton
}

\author{
By Jacques Urech \\ Swiss Federal Institute for Water Resources and Water Pollution Control (EAWAG) at Swiss Federal \\ Institutes of Technology (ETH)
}

Manuscript received on 28 June 1979

\begin{abstract}
The crustacea plankton of three artificial model lakes in Lake Baldegg was observed during 15 months. Two were loaded continuously with low concentrations of five heavy metals $(\mathrm{Hg}, \mathrm{Cu}, \mathrm{Cd}, \mathrm{Zn}, \mathrm{Pb})$.

It was attempted to explain the significant lower abundances of the loaded limno-corrals. The results suggest that the decrease was not, or only partially, caused by the lower food supply in the loaded limnocorrals, but directly by the heavy metals.

Accompaning laboratory tests show significantly increased egg-development-times for two species of those animals from the loaded limno-corrals. Two other species show a decrease of the egg production/ 9 . It cannot be determined if increased mortality of particular animal stages was caused by heavy metals.
\end{abstract}

\section{Introduction}

Zooplankton is an important link in the food chain of stagnant waters. It was the goal of this paper to investigate its reaction to slightly elevated $\mathrm{Hg}, \mathrm{Cu}, \mathrm{Cd}, \mathrm{Zn}$ and $\mathrm{Pb}$ concentrations over a period of 15 months. In contrast to short-time laboratory tests, the MELIMEX program [12] allowed the study of zooplankton populations at nearly natural environmental conditions.

Based on the abundances of the various species, the stages and sexes within the species, as well as on a laboratory test to determine the egg-development-time, it was attempted to explain the observed decrease of the zooplankton density in the metal-loaded limno-corrals. The questions here raised are the following: Is in metalloaded limno-corrals the fertility decreased, the mortality increased or is growth inhibited during all or particular life stages? Are observed differences in zooplankton density and species abundance direct results of elevated metal concentrations or, indirect effects of metal-induced changes in phytoplankton species composition [13], causing changes in food supply.

For reasons of simplification, the investigations were restricted to the large species of the crustacea plankton, which contribute most to the total zooplankton biomass. Rotifers, naupliar stages and smaller crustaceans were excluded.

There are number of laboratory tests investigating the influence of trace metals on a 
variety of marin and freshwater zooplankton species $[1,5-7,11,17,18,22,24-27$, 30,31 . However, field experiments have only been conducted with marin zooplankton $[4,15,16,28]$. This work seems to be the first one investigating the influence of elevated metal concentrations on a natural freshwater zooplankton community.

\section{Methods}

Only a summary of the experimental design is given here. For more detail information see Gächter [12].

The experimental layout consists of three round $(\varnothing 12 \mathrm{~m})$ containers, about $10 \mathrm{~m}$ deep, in the litoral of an eutrophic Swiss lake. Two of these limno-corrals (L1, L2) were continuously loaded with five heavy metals.

The average input concentrations to limno-corrals L1 and L2 were:

Hg: $0.5 \times 10^{-8} \mathrm{M}=1.00 \mu \mathrm{g} / 1$,

$\mathrm{Cu}: 18 \times 10^{-8} \mathrm{M}=11.44 \mu \mathrm{g} / \mathrm{l}$,

Cd: $4.5 \times 10^{-8} \mathrm{M}=5.06 \mu \mathrm{g} / 1$,

$\mathrm{Zn}: 320 \times 10^{-8} \mathrm{M}=209.18 \mu \mathrm{g} / \mathrm{l}$,

$\mathrm{Pb}: 24 \times 10^{-8} \mathrm{M}=49.73 \mu \mathrm{g} / \mathrm{l}$.

These concentrations are approximately in agreement with the maximum values legally tolerated for Swiss running waters. Increased metal loading of limno-corrals L1 and L2 was started on 4 April 1977 and ended on 30 June 1978. The third corral (C) served as control. The inflow was filtered (pore size $54 \mu \mathrm{m}$ ) lake water. Between 22 March 1977 and 28 June 1978 zooplankton was sampled in about biweekly intervals. Samples consisted of several replicate net hauls, taken in the center of the corrals at about noon. The diameter of the net opening was $26 \mathrm{~cm}$, the length of the net $100 \mathrm{~cm}$ and the mesh size $300 \mu \mathrm{m}$.

Every net-haul brought in animals between the top of the net in $8 \mathrm{~m}$ depth (i.e. at the bottom of the corral) and the surface. Only during short dry-spells, was the depth of the capture decreased to $7.5 \mathrm{~m}$. The plankton was fixed with a $4 \%$ Formalin solution. Aliquots were counted, considering adult females, adult males, copepodit stages (respectively juvenile daphnids) and eggs. As copepodit stages of the closely related species Cyclops vicinus and C.abyssorum are difficult to distinguish, they were summarized in one class. Eggs released from daphnids brood pouchs were taken into account.

With only a few exceptions, animals were counted until in every counting class at least twenty specimens or the eggs of twenty, were counted, which meant for most classes that more than twenty were counted. According to Einsle [9] this results in an average error of $20 \%$. All counting results refer to $1 \mathrm{~m}^{3}$ of water (individuals per cubic meter).

In order to investigate the influence of elevated heavy metal concentrations on the duration of egg development, adult females of the limno-corrals C and L2 were kept at $15^{\circ} \mathrm{C}$ in water of their origin. Animals, which developed eggs in their brood pouch, or formed egg balls within 2 days after sampling, were separated in embryonic dishes $(40 \times 40 \mathrm{~mm}$, about $3.5 \mathrm{ml})$ and kept in the dark at four different 
temperatures $\left(5 \pm 1{ }^{\circ} \mathrm{C}, 10 \pm 1{ }^{\circ} \mathrm{C}, 15 \pm 1^{\circ} \mathrm{C}\right.$ and $\left.20 \pm 1{ }^{\circ} \mathrm{C}\right)$ in the water of their origin without additional food supply. Hatching of the eggs was registered daily. With a few exceptions (see results) for every taxonomic class the egg-development-time based on 20 egg-carrying animals. In table 1 the metal concentrations in the water of $\mathrm{L} 2$ and $\mathrm{C}$ at the time of this test are compiled.

Table 1. Metal concentrations in the filtered water of $\mathrm{L} 2$ and $\mathrm{C}$ during the egg-development-tests. Tabelle 1. Metallkonzentrationen des gefilterten Wassers der Behälter $\mathrm{L} 2$ und $\mathrm{C}$ während der Versuche zur Bestimmung der Eientwicklungszeiten.

\begin{tabular}{llr}
\hline & $\mathrm{L} 2$ & $\mathrm{C}$ \\
\hline $\mathrm{Hg}$ & $<0.05 \times 10^{-8} \mathrm{M}$ & $<0.05 \times 10^{-8} \mathrm{M}$ \\
$\mathrm{Cu}$ & $10.3 \times 10^{-8} \mathrm{M}$ & $1.1 \times 10^{-8} \mathrm{M}$ \\
$\mathrm{Cd}$ & $1.17 \times 10^{-8} \mathrm{M}$ & $0.05 \times 10^{-8} \mathrm{M}$ \\
$\mathrm{Zn}$ & $110 \times 10^{-8} \mathrm{M}$ & $14.5 \times 10^{-8} \mathrm{M}$ \\
$\mathrm{Pb}$ & $1.25 \times 10^{-8} \mathrm{M}$ & $0.05 \times 10^{-8} \mathrm{M}$ \\
\hline
\end{tabular}

\section{Results and discussion}

Due to its highly eutrophic character, Lake Baldegg (see Gächter [12]), is poor in species composition. The missing fish predation and the simple geometric forms of the corrals may have even intensified this fact. Actually, apart from the four most important species Daphnia longispina, Eudiaptomus gracilis, Cyclops vicinus, Cyclops abyssorum, only a few representatives of four further species, i.e. Eucyclops serrulatus, Macrocyclops albidus, Chydorus sphaericus and Bosmina sp. were observed.

Table 2. Average contribution of the four numerous and the four rare species of the whole number of zooplankton individuals (without cyclopid copepodits).

Tabelle 2. Durchschnittlicher Anteil der vier häufigen und der vier seltenen Arten an der

Gesamtindividuenzahl des Zooplanktons (ohne Copepodite der Cyclopiden).

\begin{tabular}{llr}
\hline & Numerous species $(\%)$ & Rare species $(\%)$ \\
\hline L1 & 99.1 & 0.9 \\
L2 & 99.2 & 0.8 \\
C & 99.6 & 0.4 \\
\hline
\end{tabular}

Average contributions of abundant and rare species to the total number of zooplankton individuals are shown in table 2 . In these calculations the copepodits of the cyclopids were not considered, since their species composition was not evaluated. However this deficiency may not essentially influence the upper results.

Since Eucyclops serrulatus, Macrocyclops albidus, Chydorus sphaericus and Bosmi$n a$ sp. were always very low in number and frequently could not be detected at all, it cannot be decided if increased metal concentrations affected these species.

On three occasions comparisons of samples obtained from limno-corral $\mathrm{C}$ and Lake Baldegg yielded a good conformity for all four important species from qualitative and quantitative points of view.

Background information about environmental chemistry and trophic level of the lake have been given by Gächter [12]. Metal concentrations and temperatures in the 
limno-corrals have been monitored by Baccini [2, 3] and Imboden [19], respectively. Metal concentrations in phyto- and zooplankton have been determined by Gächter [14] who also measured phytoplankton standing crop and primary production [13] in the metal-polluted and the control limno-corrals. Observed abundances of all species and stages (without eggs) are plotted in figure 1 . In 28 of the 32 events, values of $\mathrm{C}$ were higher than the mean values of $\mathrm{L} 1$ and $\mathrm{L} 2$. The inverse was only observed on four occasions.

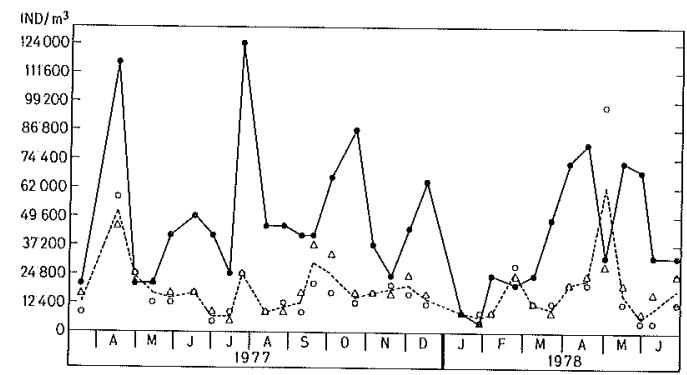

Figure 1. Crustacea plankton, total number of individuals, seasonal variation. $\mathrm{O}=\mathrm{L} 1, \triangle=\mathrm{L} 2, \quad=\mathrm{C}$.

Abb. 1. Zeitliche Abhängigkeit der Gesamtindividuenzahl des Crustaceenplanktons. $\mathrm{O}=\mathrm{L} \mathrm{I}, \Delta=\mathrm{L} 2, \mathrm{C}$.

Comparing mean values of total individuals, averaged over the period 22 March 1977 to 28 June 1978, yields nearly identical results for L1 and L2 (see table 6), which are about 2.5 -fold and thus significantly $(p<0.01)$ lower than those of the control.

Figure 2 shows the relative contribution of the most important species to the total zooplankton species number. The related species, Cyclops abyssorum and C.vicinus were unified into one group because as mentioned above their copepodit stages were not counted separately. In all limno-corrals the observed composition was typical for eutrophic lakes: i.e. in early spring the cyclopids (1977: C. abyssorum, 1978: C. vici$n u s$ ) and afterwards, throughout the summer, daphnids dominate.

Differences in species composition are much less pronounced than differences in abundance of total zooplankton individuals. The major difference in species composition is given by the delayed increase of D. longispina in L1 and L2 in spring. In the control, the onset of this increase in Daphnia density was in both years observed in May, "whereas in the metal-loaded corrals Daphnia did not start to develop until June 1977 and July 1978, respectively. Further, in the metal-loaded limno-corrals in 1977 and 1978 E.gracilis reached maximum densities between the cyclopid and the daphnid maximum in June/July, and then was an important part of the zooplankton. In contrast, in the limno-corral C, the importance of this species was negligibly small after October 1977.

The fact that all control species also occur in the loaded limno-corrals shows, in spite of all differences, mentioned above that the heavy metals, directly or indirectly damage all species present in a similar way. 

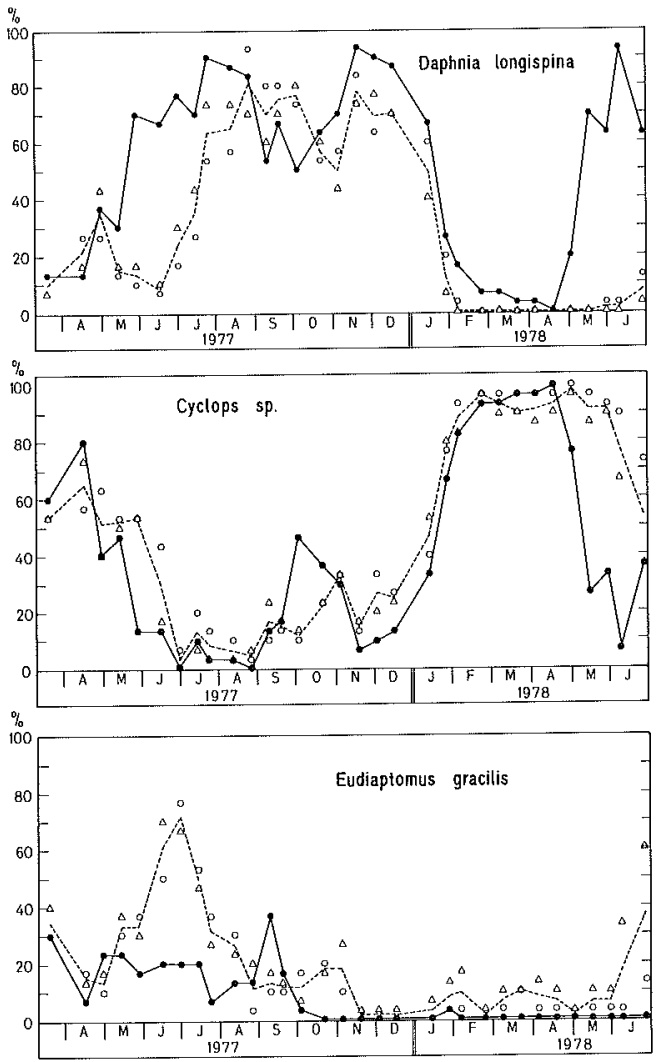

Figure 2. Part of the particular species of the total number of individuals, seasonal variation.

$$
\mathrm{O}=\mathrm{L} 1, \Delta=\mathrm{L} 2, \quad=\mathrm{C} \text {. }
$$

Abb.2. Zeitliche Abhängigkeit des Anteils der verschiedenen Arten an der Gesamtindividuenzahl des Crustaceenplanktons.

$\mathrm{O}=\mathrm{L} 1, \Delta=\mathrm{L} 2, \quad=\mathrm{C}$.

In figure 3 the abundances of females of Daphnia longispina (adults plus juveniles) are shown. The values for limno-corral $\mathrm{C}$ were distinctly higher than for $\mathrm{L}$ $[=(\mathrm{L} 1+\mathrm{L} 2) / 2]$. Similar differences between $\mathrm{L}$ and $\mathrm{C}$ can be found for adults, juveniles and eggs (not shown in this work). Males were very rare through out the experiment.

During the first part of the experiment, i.e. until September 1977, C. abyssorum was the more abundant of the two cyclopids. Afterwards, C. vicinus developed higher individual numbers (see fig.3). The nearly complete missing $C$. vicinus in the first part of the experiment could possibly be related to the diapause of this species. Diapause is the so-called resting stage of the fourth copepodit stage (C4) in the upper layers of the lake sediments (Kiefer [21]), which normally lasts from May to February (in good agreement with own observations). Because C4 normally rests in 

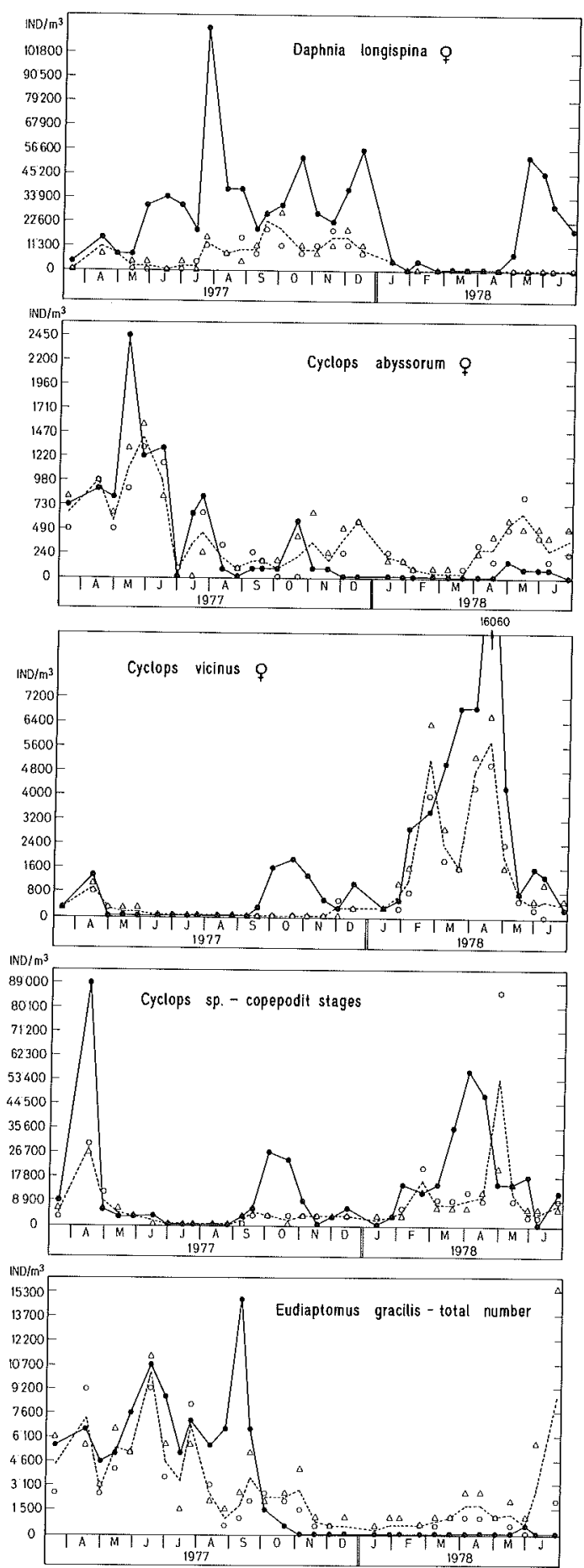

Figure 3. Number of individuals of some species, seasonal variation. (Note different $y$-axis!) $\mathrm{O}=\mathrm{L} 1, \Delta=\mathrm{L} 2, \quad=\mathrm{C}$.

Abb. 3. Zeitliche Abhängigkeit der Individuenzahlen einiger Arten. (Unterschiedlicher Maßstab der $\mathrm{y}$-Achsen!)

$\mathrm{O}=\mathrm{L} 1, \Delta=\mathrm{L} 2, \quad=\mathrm{C}$. 
the lake bottom of the pelagial, most probably only a few C4 stages were initially enclosed when the limno-corrals were exposed on November 1977 in the litoral zone of Lake Baldegg. The fact that their successors could not escape from the corrals might explain why C. vicinus became more important in the second part of the experiment.

From figure 3 (note different y-axis) it can easily be recognized, that the cyclopid populations consisted to a large extent of copepodit stages, i.e. the adults were quantitatively not important. Substantial quantitative differences between the density of copepodits of limno-corrals $C$ and $L$ were observed during three short periods. In April 1977, October 1977 and March/April 1978 the densities of C distinctly exceeded those of the metal-loaded limno-corrals. As of November 1977 C. abyssorum nearly completely disappeared in limno-corral C. Since according to Kiefer [21] C. vicinus in contrast to C. abyssorum prefers highly eutrophic conditions, the distinct differences in primary production of limno-corrals $\mathrm{L}$ and $\mathrm{C}$ (see Gächter [13]) probably could explain why C.abyssorum disappeared nearly completely in C but was not extincted as strongly in limno-corrals L1 and L2. Eudiaptomus gracilis was significantly $(\mathrm{p}<0.05)$ more abundant in limno-corral $\mathrm{C}$ than in $\mathrm{L} 1$ and L2 until September 1977. However, after September 1977 this species disappeared nearly completely in the control. Because at this time the partially carnivorous species $C$. vicinus increased very rapidly in limno-corral C, the decrease of E. gracilis and C.abyssorum might partially be the result of increased predation by $C$. vicinus.

Several authors $[5,22,28,30,31]$ have shown that the ratio eggs/ 9 reacts very sensitively to changes of the heavy metal concentrations. In the four investigations conducted with freshwater cladocerans a slight increase of metal concentration, seemed to stimulate the egg number/9 ratio or fecundity, in at least part of the tests. At high metal concentrations this ratio normally was decreased.

Figure 4 shows eggs/ 9 ratios for those periods, in which in samples of all limnocorrals at least 20 egg-carrying animals were found. For C. vicinus and C. abyssorum distinctly lower ratios were found in $L$ during the periods January to April 1978 and June to August 1977, respectively. The opposite, i.e. higher egg/ 9 ratios in L than in C, was only very rarely observed. For D. longispina and E. gracilis these ratios were not significantly different in $\mathrm{L}$ and $\mathrm{C}$ corrals.

In order to answer the question if in the metal-loaded corrals the restricted food supply was the reason for the lower zooplankton abundances, correlations between chlorophyll concentrations and eggs/ $q$ adult were investigated. In natural waters, this ratio is relative closely connected with the available food $[20,23]$. As a measure of food supply the chlorophyll concentration of the preceding sampling date was chosen ( $\Delta \mathrm{t} \approx 14$ days). Table 7 shows that in limno-corral $\mathrm{C}$, fecundity was significantly correlated to chlorophyll concentration for all investigated species. In contrast these correlations were not significant for averaged values of limno-corrals $\mathrm{L} 1$ and L2. Assuming that the food quality of algae in limno-corrals $\mathrm{C}$ and $\mathrm{L}$ did not differ substantially, these correlations point to a disturbance of the relation chlorophyll/(eggs/ $\$$ adult) in the metal-loaded limno-corrals. Correlation analysis yielded significant negative correlations $(\mathrm{p}<0.05)$ between eggs $/ q$ adult and heavy metal concentrations in the medium for E.gracilis (eggs/ $q$ adult) and $\mathrm{Zn}$, and C. vivinus (eggs/ 9 adult) and $\mathrm{Cu}, \mathrm{Pb}$ and $\mathrm{Cd}$. 

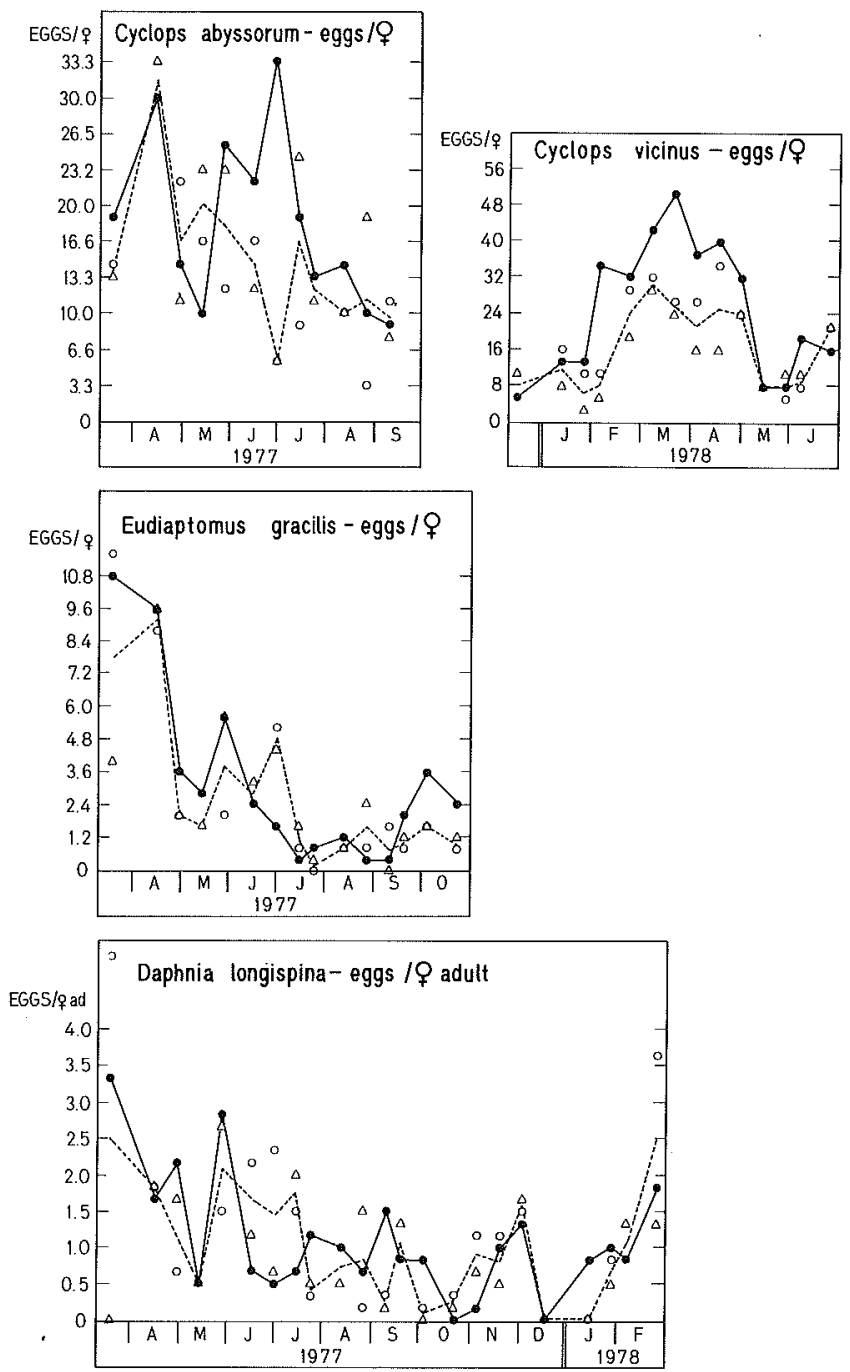

Figure 4. Seasonal variation of egg/ 9 ratio. (Note different $y$-axis!)

$$
\mathrm{O}=\mathrm{L} 1, \triangle=\mathrm{L} 2, \quad=\mathrm{C} \text {. }
$$

Abb.4. Zeitliche Abhängigkeit des Verhältnisses Eier/ 9 . (Unterschiedlicher Maßstab der y-Achsen!) $\mathrm{O}=\mathrm{L} 1, \Delta=\mathrm{L} 2, \mathrm{C}=\mathrm{C}$.

The observed depression in fecundity of the two cyclopid species and its uncoupling to chlorophyll concentration in limno-corrals $\mathbf{L} 1$ and $\mathrm{L} 2$, points to a direct adverse effect of the increased heavy metal concentrations.

In order to determine which stage of the animals was mainly affected by increased heavy metal concentrations, the influence of increased heavy metal concentration on the egg-development-time was investigated in a first step.

According to Elster [10], the eggs of E. gracilis are within the natural variation of environmental conditions, rather unsensitive to changes of $\mathrm{pH}$, food supply, light 
conditions, $\mathrm{CaCO}_{3}$, but the time needed for their development depends strongly on the temperature. Eichhorn [8] confirmed these observations for Mixodiaptomus laciniatus and Acanthodiaptomus denticornis. During the measurements of the eggdevelopment-times, the water in the limno-corrals C and L2 differed substancially only in food supply and metal concentrations. $\mathrm{pH}$ was in the range of 7.9-9.0 in $\mathrm{C}$ and in the range of 8.0-9.4 in L2.

Table 3. Mean values of the egg-development-times of D. longispina in L2 and C, standard deviation, number of tested animals (n), probability (p) for difference of $\mathrm{C}$ and $\mathrm{L}$ values.

Tabelle 3. Mittelwerte der Eientwicklungszeiten von D. longispina in L2 und C, Standardabweichung, Anzahl untersuchter Tiere, Wahrscheinlichkeit für ungleiche C- und L-Werte.

\begin{tabular}{rllllllr}
\hline Temperature $\left({ }^{\circ} \mathrm{C}\right)$ & Mean value L2 & $\mathrm{n}$ & $\mathrm{s}$ & Mean value C & $\mathrm{n}$ & $\mathrm{s}$ & $\mathrm{p}$ for difference $(\%)$ \\
\hline 5 & 13.50 & 20 & 1.40 & 11.60 & 20 & 1.88 & 99.9 \\
10 & 7.90 & 20 & 0.91 & 6.70 & 20 & 1.34 & 98.8 \\
15 & 5.70 & 20 & 1.13 & 4.80 & 20 & 1.24 & 98.0 \\
20 & 4.00 & 20 & 0.97 & 2.95 & 20 & 0.60 & 100.0 \\
\hline
\end{tabular}

Table 4. Mean values of the egg-development-times of E. gracilis in L2 and C, standard deviation, number of tested animals ( $\mathrm{n}$ ), probability (p) for difference of $\mathrm{C}$ and $\mathrm{L}$ values.

Tabelle 4. Mittelwerte der Eientwicklungszeiten von E. gracilis in L2 und C, Standardabweichung, Anzahl untersuchter Tiere, Wahrscheinlichkeit für ungleiche C- und L-Werte.

\begin{tabular}{rllllllr}
\hline Temperature $\left({ }^{\circ} \mathrm{C}\right)$ & Mean value L2 & $\mathrm{n}$ & $\mathrm{s}$ & Mean value C & $\mathrm{n}$ & $\mathrm{s}$ & $\mathrm{p}$ for difference $(\%)$ \\
\hline 5 & 14.15 & 20 & 1.57 & 12.75 & 20 & 2.12 & 97.8 \\
10 & 7.15 & 20 & 0.99 & 6.15 & 20 & 1.27 & 99.2 \\
15 & 3.90 & 20 & 1.02 & 3.60 & 20 & 0.88 & 67.2 \\
20 & 2.75 & 20 & 1.02 & 2.40 & 20 & 0.68 & 79.3 \\
\hline
\end{tabular}

Table 5. Mean values of the egg-development-times of $C$. vicinus in $\mathrm{L} 2$ and $\mathrm{C}$, standard deviation, number of tested animals ( $\mathrm{n}$ ), probability (p) for difference of $\mathrm{C}$ and $\mathrm{L}$ values.

Tabelle 5. Mittelwerte der Eientwicklungszeiten von C. vicinus in L2 und C, Standardabweichung, Anzahl untersuchter Tiere, Wahrscheinlichkeit für ungleiche C- und L-Werte.

\begin{tabular}{rllllllr}
\hline Temperature $\left({ }^{\circ} \mathrm{C}\right)$ & Mean value L2 & $\mathrm{n}$ & $\mathrm{s}$ & Mean value $\mathrm{C}$ & $\mathrm{n}$ & $\mathrm{s}$ & $\mathrm{p}$ for difference $(\%)$ \\
\hline 5 & 8.75 & 12 & 0.97 & 9.12 & 17 & 1.54 & 52.3 \\
10 & 6.21 & 14 & 0.89 & 5.67 & 12 & 0.98 & 85.4 \\
15 & 3.64 & 14 & 0.74 & 3.92 & 13 & 0.76 & 65.5 \\
20 & 2.67 & 15 & 0.62 & 2.75 & 12 & 0.62 & 73.1 \\
\hline
\end{tabular}

Due to the extremely low density of C.abyssorum which did not allow for the collection of the required number of adults, this species had to be excluded from these tests. For all temperatures tested, egg-development-times for D. longispina were significantly $(\mathrm{p}<0.05)$ shorter in C than in L2 (see table 3 ). The same trend as observed for D. longispina was found for E. gracilis (see table 4). The eggs of control organisms developed faster than those of animals sampled from L2. But, contrary to D. longispina at increased temperatures $\left(15\right.$ and $\left.20^{\circ} \mathrm{C}\right)$ the mean values were not significantly different between $\mathrm{C}$ and $\mathrm{L} 2$. For C.vicinus, at none of the tested temperatures were there significant differences between the data of $\mathrm{L} 2$ and $\mathrm{C}$ (see table 5). 


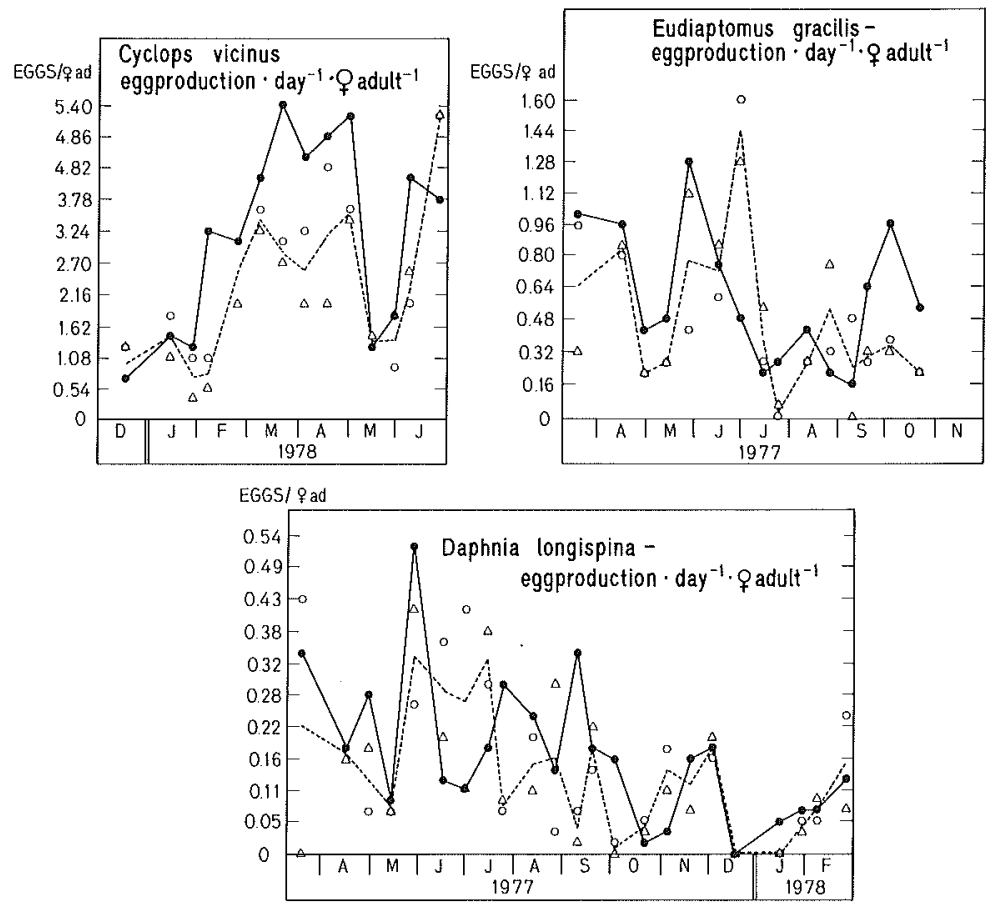

Figure 5. Seasonal variation of egg production/day $\cdot$.. (Note different y-axis!)

Abb. 5. Zeitliche Abhängigkeit von Eiproduktion/Tag. ‥ (Unterschiedlicher Maßstab der y-Achsen!) $\mathrm{O}=\mathrm{L} 1, \Delta=\mathrm{L} 2, \mathrm{C}$.

Metal-induced changes of the egg-development-time could also affect the ratio eggs $/ \$$. If this ratio is divided by the experimentally determined egg-developmenttime at the corresponding temperature, information about egg production/day. $q$ can be obtained. Figure 5 shows estimated egg-production rates for all abundant species except C.abyssorum. For C.vicinus distinctly higher egg-production rates were observed in the control as compared to the limno-corrals L1 and L2. This depression of fecundity in the metal-polluted limno-corrals might explain the higher density in the control from January to June 1978. In contrast to C. vicinus, eggproduction rates of C.abyssorum seemed not to be inhibited by the elevated metal concentrations. Since also abundances did not differ between $\mathrm{L}$ and $\mathrm{C}$ limno-corrals it must be assumed that this species is relatively insensitive towards heavy metals. Since for D. longispina and E.gracilis figure 5 no systematic difference of fertility were observed, the lower densities in L can only be explained by increased mortality.

To determine in which stage of life the heavy metals mainly caused increased mortality, the ratios juveniles/eggs and adults/juveniles were calculated for all abundant species. For $C$. vicinus and C. abyssorum no differences of these ratios were observed. This suggests that lower abundances in limno-corrals L1 and L2 were mainly the result of the observed depression in fecundity with or without an additional increased non-stage specific mortality. 
Table 6. Mean values of all zooplankton individuals together $\left(\right.$ per $\left.\mathrm{m}^{3}\right)$ and standard deviation of all the limno-corrals.

Tabelle 6. Mittelwerte der Gesamtzooplankton-Individuenzahlen (jeweils für einen $\mathrm{m}^{3}$ ) und Standardabweichung für die einzelnen Behälter.

\begin{tabular}{llr}
\hline Limno-corral & Mean value, total of & Standard deviation \\
& zooplankton individuals & 17,505 \\
\hline L1 & 18,144 & 9,100 \\
L2 & 17,801 & 28,494 \\
C & 46,665 & \\
\hline
\end{tabular}

Table 7. Correlations between chlorophyll concentrations and the ratio eggs/ 9 adult, probability for significancy.

Tabelle 7. Korrelationskoeffizienten für Chlorophyllgehalt und das Verhältnis Eier/ㅇ adult, Wahrscheinlichkeit für Signifikanz.

\begin{tabular}{llclr}
\hline & C & p for significancy & L & p for significancy \\
\hline Daphnia longispina & 0.622 & 100.0 & 0.332 & 92.5 \\
Eudiaptomus gracilis & 0.460 & 98.8 & 0.317 & 90.9 \\
Cyclops vicinus & 0.610 & 100.0 & 0.236 & 78.5 \\
\hline
\end{tabular}

This in general also holds for D.longispina and E.gracilis except for the period April 1977 to September 1977 when the ratio adults/juveniles was approximately twice as high in $\mathrm{L}$ as in $\mathrm{C}$. Since increased metal concentrations did not depress fecundity of either E. gracilis or D. longispina, the observed depression of densities in L1 and L2 can with no doubt only be explained by the increased mortality rates. The partial contradictory ratios adults/juveniles and juveniles/eggs do not allow a clear differentiation if the mortality rates are elevated generally or only for particular stages.

\section{Summary}

1. Two limno-corrals which separated $1,130 \mathrm{~m}^{3}$ water from the rest of Lake Baldegg, were continuously loaded with the heavy metals $\mathrm{Hg}, \mathrm{Cu}, \mathrm{Cd}, \mathrm{Zn}, \mathrm{Pb}$ over a period of 15 months. Another limno-corral of the same size served as control.

2. In this period crustacea plankton was sampled 32 times in about biweekly intervals.

3. Only these four following, of the eight species having been found, were of great importance: Daphnia longispina, Eudiaptomus gracilis, Cyclops abyssorum, Cyclops vicinus.

4. On the average, there were found 2.5 times more animals in the control than in the loaded limno-corrals.

5. The lowered zooplankton densities in the loaded limno-corrals are probably caused directly by adverse effects of the increased heavy metal concentrations and not indirectly by a changed food supply.

6. In the metal-loaded limno-corrals the egg-development-times of D. longispina and E.gracilis were significantly extended. However, no such a delay was found for C. vicinus. 
7. Increased metal concentration decreased egg production/ 9 of C.vicinus and C. abyssorum, but not of the other species.

8. It was tried to reduce the generally increased mortality in the loaded limnocorrals to the mortality of a particular stage, by investigating the ratios adults/juveniles and juveniles/eggs. But none of the species showed such an increased mortality of a particular stage.

\section{ZUSAMMENFASSUNG}

A uswirkungen erhöhter Schwermetallkonzentrationen auf Crustaceenplankton

1. Zwei Behälter, die je $1130 \mathrm{~m}^{3}$ Wasser vom übrigen Teil des Baldeggersees abtrennten, wurden während 11/4 Jahren kontinuierlich mit den Schwermetallen $\mathrm{Hg}, \mathrm{Cu}, \mathrm{Cd}, \mathrm{Zn}, \mathrm{Pb}$ belastet. Ein weiterer, gleich grosser Behälter diente als Kontrolle.

2. In diesem Zeitraum wurden annähernd 14täglich 32mal Crustaceenplankton-Proben genommen.

3. Von acht vorkommenden Arten waren nur die folgenden vier mengenmässig von Bedeutung: Daphnia longispina, Eudiaptomus gracilis, Cyclops abyssorum, Cyclops vicinus.

4. Durchschnittlich wurden $2,5 \mathrm{mal}$ mehr Tiere in der Kontrolle als in den belasteten Behältern gefunden.

5. Signifikant positiv korreliert war in der Kontrolle das Verhältnis Eier/q mit dem Nahrungsangebot (Chlorophyllgehalt) gegenüber nicht signifikanten Korrelationen in den belasteten Behältern. Diese Tatsache und mehrere signifikant negative Korrelationen zwischen Eier/우 zweier Arten und einzelnen Schwermetallgehalten in den belasteten Behältern deuten auf einen wahrscheinlichen direkten Einfluss der Schwermetalle auf das Plankton hin. Erhöhte Bestandeszahlen in der Kontrolle können somit nicht allein mit grösserem Nahrungsangebot erklärt werden.

6. In einem begleitenden Laborversuch wurden die Eientwicklungszeiten von drei Arten in belastetem und unbelastetem Wasser ermittelt. Diejenigen von D.longispina und E.gracilis waren signifikant verlängert. Keine Verlängerung fand sich für $C$. vicinus.

7. Die Eiproduktion/ $q$ wurde in den belasteten Behältern für C. vicinus deutlich und für C.abyssorum schwach herabgesetzt. Die anderen Arten zeigten keine signifikanten Unterschiede.

8. Mit Hilfe der Verhältnisse Adulte/Juvenile und Juvenile/Eier wurde versucht, die generell erhöhte Mortalität in den belasteten Behältern auf erhöhte Mortalität bestimmter Lebensstadien zurückzuführen. Aufgrund der Resultate konnte keine erhöhte Sterblichkeit einzelner Stadien durch Schwermetalle festgestellt werden.

\section{RÉSUMÉ}

On a observé pendant 15 mois les crustacés planctoniques des trois modèles de lac installés dans le lac de Baldegg. Dans deux de ceux-ci, une charge constante de cinq métaux lourds $(\mathrm{Hg}, \mathrm{Cu}, \mathrm{Cd}, \mathrm{Zn}, \mathrm{Pb})$ de faible concentration a été maintenue.

On a essayé d'expliquer la faible concentration significative de plancton dans les bassins limnologiques chargés. Les résultats montrent que la diminution n'était que partiellement ou pas du tout causée par le faible approvisionnement en nourriture dans les bassins chargés, mais directement par les métaux lourds. Les tests de laboratoire montrent significativement l'augmentation du temps de développement des œufs pour deux espèces animales des bassins chargés. Deux autres espèces montrent une diminution de la production d'œufs/ㅇ․ On ne peut pas déterminer l'augmentation de la mortalité des animaux causée par les métaux lourds à des stades particuliers de développement.

\section{ACKNOWLEDGMENTS}

I appreciate and acknowledge the many helpful suggestions and criticisms, as well as the review of an earlier version of the manuscript of Dr. R. Gächter. In addition, I thank Dr. J. Davis for reading the English text and $\mathrm{H}$. Bolliger for drawing the figures. 


\section{REFERENCES}

1 Anderson, B.G.: The apparent thresholds of toxicity to Daphnia magna for chlorides of various metals when added to Lake Erie water. Trans. Am. Fish. Soc. 78, 96-113 (1948).

2 Baccini, P., Ruchti, J., Wanner, O., and Grieder, E.: MELIMEX, an experimental heavy metal pollution study: Regulation of trace metal concentrations in limno-corrals. Schweiz. Z. Hydrol. 41, 202-227 (1979).

3 Baccini, P., and Suter, U.: MELIMEX, an experimental heavy metal pollution study: Chemical speciation and biological availability of copper in lake water. Schweiz. Z. Hydrol. 41, 291-314 (1979).

4 Beers, J.R., Stewart, G. L., and Hoskins, K.D.: Dynamics of micro-zooplankton populations treated with copper: controlled ecosystem pollution experiment. Bull. Mar. Sci. 27/1, 66-80 (1977).

5 Biesinger, K.E., and Christensen, G.M.: Effects of various metals on survival, growth, reproduction and metabolism of Daphnia magna. J. Fish. Res. Board Can. 29, 1691-1700 (1972).

6 Cabejozek, I., and Stasiak, M.: Studies on the effect of some metals on water biocenosis using the Daphnia magna index, part I. Roczn. państ. Zakl. Hig. 11, 303-311 (1960) (in polish).

7 Corner, E.D.S., and Sparrow, B.W.: The modes of action of toxic agents. I. Observations of the poisoning of certain crustaceans by copper and mercury. J. mar. biol. Ass. UK 35, 531-548 (1956).

8 Eichhorn, R.: Zur Populationsdynamik der calanoiden Copepoden in Titisee und Feldsee. Arch. Hydrobiol., suppl. 24, 186-246 (1959).

9 Einsle, U.: Die Gattung Cyclops s.str. im Bodensee. Arch. Hydrobiol. 60/2, 133-199 (1964).

10 Elster, H.-J.: Über die Populationsdynamik von Eudiaptomus gracilis Sars und Heterocope borealis Fischer im Bodensee-Obersee. Arch. Hydrobiol., suppl. 20, 546-614 (1954).

11 Fischer, A.: The effect of copper sulphate on some microorganisms in fish ponds. Bamidgeh $8,21-$ 27, 39-43 (1956).

12 Gächter, R.: MELIMEX, an experimental heavy metal pollution study: Goals, experimental design and major findings. Schweiz. Z. Hydrol. 41, 169-176 (1979).

13 Gächter, R., and Máreš, A.: MELIMEX, an experimental heavy metal pollution study: Effects of increased heavy metal load on phytoplankton populations. Schweiz. Z. Hydrol. 41, 228-246 (1979).

14 Gächter, R., and Geiger, W.: MELIMEX, an experimental heavy metal pollution study: Behaviour of heavy metals in an aquatic food chain. Schweiz. Z. Hydrol. 41, 277-290 (1979).

15 Gamble, J.C., Davies, J.M., and Steele, J.H.: Loch Ewe bag experiment. Bull. Mar. Sci. 27/1, 146 175 (1977).

16 Gibson, V.R., and Grice, G.D.: Response of macro-zooplankton populations to copper: controlled ecosystem pollution experiment. Bull. Mar. Sci. 27/1, 85-91 (1977).

17 Holm-Jensen, I. B.: Osmotic regulation in Daphnia magna under physiological conditions and in the presence of heavy metals. Kgl. danske Vidensk. Selsk. Biol. Medd. XX, 11 (1948).

18 Hueck, H.J., and Adema, D.M.M.: Toxicological investigations in an artificial ecosystem. A progress report on copper toxicity towards algae and daphniae. Helgoländer wiss. Meeresunters. 17, $188-199$ (1968).

19 Imboden, D.M., Eid, B.S.F., Joller, T., Schurter, M., and Wetzel, J.: MELIMEX, an experimental heavy metal pollution study: Vertical mixing in a large limno-corral. Schweiz. Z. Hydrol. 41, 177-189 (1979).

20 Ingle, L., Wood, T.R., and Banta, A.M.: A study of the longevity, growth, reproduction and heart rate in Daphnia longispina as influenced by limitations in quantity of food. J. exp. Zool. 76, 325-352 (1937).

21 Kiefer, F., and Fryer, G.: Das Zooplankton der Binnengewässer. Binnengewässer 26, part 2 (1978).

22 Marshall, J.S.: Population Dynamics of Daphnia galeata mendotae as Modified by Chronic Cadmium Stress. J. Fish. Res. Board Can. 35, 461-469 (1978).

23 Munro Fox, H., Hardcastle, S. M., and Dresel, E.I.B.: Fluctuations in the haemoglobin content of Daphnia. Proc. R. Soc., Lond. (B) 136, 388-399 (1949).

24 Naumann, E.: Über die Toxizität des Bleichlorids für Daphnia magna. Kungl. fysiogr. Sällsk. Lund Forh. 4, 14 (1934).

25 Naumann, E.: Über die Toxizität des Kupfersulfats für Daphnia magna. Kungl. fysiogr. Sällsk. Lund Forh. 4, 5 (1934).

26 Naumann, E.: Über die Toxizität des Zinksulfats für Daphnia magna. Kungl, fysiogr. Sällsk. Lund Forh. 4, 13 (1934). 
27 Parrish, K.M., and Carr, R.A.: Transport of mercury through a laboratory two-level marine food chain. Mar. Pollut. Bull. 7, No.5 (1976).

28 Reeve, M.R., Walter, M. A., Ikeda, T., and Daroy, K.: Evaluation of potential indicators of sub-letal toxic stress on marine zooplankton (feeding, fecundity, respiration and excretion): Controlled ecosystem pollution experiment. Bull. Mar. Sci. 27/1, 105-113 (1977).

29 Sonntag, N.C., and Greve, W.: Investigation of the impact of mercury on enclosed water columns using a zooplankton simulation model. J. Fish. Res. Board Can. 34, 2295-2307 (1977).

30 Winner, R.W., and Farrell, M.P.: Acute and chronic toxicity of copper to four species of Daphnia J. Fish. Res. Board Can. 33, 1685-1691 (1976).

31 Winner, R.W., Keeling, T., Yeager, R., and Farrell, M.P.: Effect of food type on the acute and chronic toxicity of copper to Daphnia magna. Freshw. Biol. 7, 343-349 (1977).

Address of the author: Jacques Urech, Seenforschungslaboratorium EAWAG/ETH, CH-6047 Kastanienbaum, Switzerland. 